\title{
THE MATTER OF FORMATION OF HUMAN BEING DESCRIBED BY THE HOLY QURAN IN COMPARISON WITH THE HISTORY OF EMBRYOLOGY
}

\author{
Imtiaz Bashir*, Azal Ikhlaq, Huniya Binte Riaz, Farhat Ijaz, Khurram Aftab \\ Department of Physiology, Combined Military Hospital Lahore Medical College, \\ Punjab Institute of Cardiology \\ Jail Rd ‘Shadman 1 Shadman, Lahore, Punjab, Pakistan. 54840 \\ *Email: imtiazbashir7@gmail.com
}

\begin{abstract}
What is the matter of creation of human? This question has been addressed since long back in the history from ancient Indian and Egyptian civilizations to the Greeks and until the advent of modern sciences. The answers to this question were varying and led to various ideologies about the paternity of the newborn and the role and importance of women in society. More or less the concept was that the human is formed from the male semen and female menstrual blood where semen is the actual matter of formation and the part of the female is just to nourish and nurture; until it is proved by the modern science that both male and female gametes equally take part in the formation of embryo. However, the Islamic Holy scripture, the Quran, and the narrations from Islamic prophet (PBUH) and the descriptions of the Islamic scholars stand in opposition to these concepts and have a stunning correlation with the modern scientific descriptions of the embryology.
\end{abstract}

Keywords: history of embryology, Islam and embryology, matter of creation of human, Quran and science

\begin{abstract}
Abstrak: Bagaimana penciptaan manusia? Pertanyaan ini telah dibahas sejak lama dalam sejarah, mulai dari peradaban India dan Mesir kuno hingga Yunani dan akhirnya munculnya ilmu pengetahuan modern. Jawaban atas pertanyaan ini bermacam-macam dan memunculkan berbagai ideologi tentang paternitas bayi baru lahir dan peran serta pentingnya perempuan dalam masyarakat. Konsepnya adalah bahwa manusia dibentuk dari air mani laki-laki dan darah haid perempuan dimana air mani adalah materi pembentuk yang sebenarnya dan bagian dari perempuan hanya untuk proses pemeliharaan; sampai dibuktikan oleh ilmu pengetahuan modern bahwa gamet jantan dan betina sama-sama berperan dalam pembentukan embrio. Namun, kitab suci Islam, Alquran, dan riwayat dari nabi Islam (SAW) dan deskripsi ulama menentang konsep-konsep ini dan memiliki korelasi yang menakjubkan dengan deskripsi ilmiah modern tentang embriologi.
\end{abstract}

Kata Kunci: Alquran dan sains, Islam dan embriologi, materi penciptaan manusia, sejarah embriologi

\section{Introduction}

The study of development of organisms is called Embryology. Embryology stands hand in hand with the history of embryology in the sense that even at the oldest times children were born. Perhaps, the practitioners of folk-medicine of that time confined their ideas to simple obstetrics. Yet, they could not have helped some presage on the development and growth of the embryo. The old Egyptian civilizations had some concepts about the developing human. In the Pharaoh dynasty, there was royal post namely 'The Opener of King's Placenta'. Placenta was given a huge reverence and considered to be the seat of soul (Blackman, 1916).

Early study of embryology can be traced back in Hindu religious scriptures such Bhagvata Purana, Garbha Upanishad and Sushruta Samhita (the first known book on Surgery), Pre-Socratic, and Hippocratic ages. Hippocrates was the first to experimentally describe the development of a chick and thereby tentatively describing the development of Human. After Hippocrates, Aristotle described the development of human in detail in his works. In the Old Testament, in the Book of Wisdom, two verses refer to the embryonic development of human. The great physician and surgeon of Roman Empire Galen in 2nd and 3rd century AD, discussed embryonic development of human in detail in his works. Afterwards, details of embryological development occur in Talmud.

Then till 16th century, no special advancements in this field are recorded when scientists like Harvey, Leonardo De Vinci, Fabricius and others did dissections and described the developing embryo (Kleiss, 1964). Later, scientists like Leeuwenhoek and Malpighi described the subject and substantiated 
the concept of preformationism. However, all these studies were under the influence of ancient Greek ideas.

The developmental cycle of female ovum in the mammals was discovered as late as 19th century. It was the phase of history in search for 'mechanisms.' Embryological investigations shifted from the description of observations to the intervention and manipulation of the developing organisms. Now, the phases of human development along with the details of chemical and physiological process are well known. A lot of research has been done in previous few years (Oppenheimer \& Willier, 1964).

Islam is one of the greatest influences on the history of world. The famous Historian Michael Hart considers the Islamic Prophet, Muhammad (SAW) as the most influential person in the history, eminently successful on both religious and secular grounds in. He regarded him as an immensely effective political leader and Islam as one of the world's greatest religion and that the influence of the prophet is still powerful and pervasive (Hart, 2000).

The Quran is the religious scripture of the Muslims which was revealed upon Islamic Prophet Muhammad SAW through the angel Gabriel in bits in a time period of 23 years and was compiled later by himself and afterwards by the Islamic Caliphs (Sherazi, 2005). The prime subject of the Quran is 'Man'. It guides the mankind in the formation of an ideal society uplifting the human individually and as a society collectively. In doing so, it touches various branches of scientific knowledge for the sake of example, reference and elaboration. Embryology is one of them.

Several verses of the Quran and narrations from the Islamic Prophet (known as Hadith) discuss human embryological development. Muslim scholars and commentators have discussed those verses with reference to the science of their time i.e. Greek philosophy. Still, the other meanings of the verses which are beyond the scope of their knowledge, they left them for upcoming generations. With the advancement of knowledge in the field of Embryology, there is a need to revisit those meanings of these verses and narrations and relate them to the modern science. This article is an attempt to revisit one of such concepts; what is the source or matter of creation of the embryo?

The matter of creation of human is of a great curiosity in the history of Embryology. It took an awfully long time to science to get the process of fertilization (as early as a century ago). Before that some ancient ideas were being followed. Let us discuss them one by one:

\section{A. The Indian Beliefs}

It is described in Bhagvata Purana Canto 3.31.1:

"the soul is made to enter the womb of a woman through the particle of a male semen to assume a particular type of the body."

The old Indian scripture on surgery 'Sushruta Samhita' dated back to 878CE6b describes that a mixture of semen and menstrual blood is the matter of development of human and that both originate from chyle (Bhishagratna, 1907). Eliciting further development, other writings state that a heat induced chemical changes occurs in the mixture which results in the formation of seven layers of skin which are comparable to the creamy layers of milk (Webb, 1848). They considered the development of human comparable to the vessel of milk which has process of fermentation to form a kind of cheese (Needham, 2015).

It is interesting to note that in Indian society, if the female has her first menstrual cycle in the house of her father, it is considered a great crime. They consider it equivalent of destruction of a soul as the menstrual blood is the substratum for the development of human according to them (Marie, 1923).

\section{B. The Pre-Socratic Beliefs}

The Pre-Socratic beliefs are extracted from the writings of Plutarch of Chaeronea (Blackman, 1969) Empedocles of Acragas (444 BC) believed that the human embryo drives its composition out of four blood vessels, two are veins and two are arteries. He describes the formation of various parts of the body through varying amount and combinations of air, water, fire, and earth. 


\section{Hippocratic Embryology}

Hippocrates describes the development of human from two seeds, one from male and one from female. He describes the semen as the fire constituent and the female seed as the earth and the interactions between the two result in the formation of human (Potter, 2012).

\section{Aristotelian Embryology}

Before Aristotle the common concept about human development was preformationism, that the seed or semen has the whole human in it and it is implanted into the female womb just as a seed is implanted into the land to produce plants, and this seed grows in size to produce the human (Maienschein, 2008). This was the reason that it was a common Greeco-Egyptian belief that only the father produces the child. As Deodrous Sicilian mentions that the Egyptians considered the father alone to be the parent of the child and that the mother provides nidus and nourishment only (Heartland, 1909). For the Greece view a passage in famous Greek drama Eumenides of Aeschylus is enough supportive reference where in a trial scene Apollo is made to say in the defense of Orestes that: "is no parent of it, but nurse only of the young life that is sown into her. The parent is male and she but a stranger, a friend, who, if fate spares his plant, preserves it till it puts forth."

However, Aristotle (384-322 B.C.) believed that the semen gives 'form' to the embryo and female contributes a matter suitable for shaping. He established that the matter contributed by the female is actually menstrual blood and not any form of semen as some earlier philosophers perceived. He affirms that male is the active while female forms the passive part of the embryo such that the dynamic male element gives shape to the plastic female element. As an analogy he says that the material secreted in the female uterus is fermented by the semen of a male in the same manner as curd acts on milk (Peck, 1943).

\section{E. Epicurean Belief}

The Epicureans thought that both male and female contributed seed in the development and the resulting fetus is fed in utero by the blood or amniotic fluid. It is depicted by the lines of Lucretius:

1. A matter of great moment 'tis the truth

2. That seed may mingle readily with the seed

3. Suited for procreation and that thick

4. Should mix with fluid seed, with thick the thick (Baile, 1910)

\section{F. The Old Testament}

The old testament of the Bible says:

"Remember, I beseech thee, that thou has fashioned me as clay, and with me into the dust again! Has thou not poured me out as milk, and curdled me like cheese? Thou has clothed me with skin and flesh and knit me together with bones and sinews" (Book of Job 10:10).

At the other place it states:

"In the womb of mother was I moulded into flesh in the time of ten months, being compacted with the blood of the seed of man and pleasured that accompanieth sleep." (Wisdom of Solomon vii:2).

These are the only instances where Bible refers to the embryonic development of human and both are simply repetition of the Aristotelian ideas.

\section{G. The Galenic Embryology}

Galen held the view that semen is the seed implanted into the womb and the embryo develop initially from the menstrual blood and later on by the blood. The embryo, as Galen says, is formed in four stages: (1) A seminal stage; (2) A stage in which three principle organs, heart, liver, and brain are engendered; (3) A stage of mapping out of body parts; and (4) A stage when the fetus is visible as a newborn (Brock, 1916). 


\section{H. The Talmud}

The Talmudic writings on the developing human also describe that the embryo being formed of menstrual blood and semen. According to Talmud, as male sows white, so the light-colored structures like bones, tendons, nails, marrow of head, and white of eye are derived from it and similarly the dark structures like cornea is derived from mother who contributes blood which is 'red'. These descriptions are a repetition of Hippocratic ideas that some part of the fetus is formed from sperm and the other from menstrual blood (Kitchell \& Resenick, 1999).

\section{The Later Scientists}

The idea that the embryo was formed out of semen and menstrual blood was believed till late 19th century until the microscope was invented and the stages of mammalian ovarian cycle were determined. For the sake of reference, I quote some examples: Female seed is coagulated like cheese by the male seed in the presence of a humidity which is menstrual blood (Aquinas, 1982). Female generative probity is inactive and just provides the substratum which is acted upon the male generative part to form the finished product (Meyer, 1939).

A theory that got popularity was the three-bubble theory according to which semen, milk, and blood consolidate in the womb and form three bubbles latter on which formed brain, heart, and lungs. This theory was supported by Ambrose Pare' (1570), Robert Feud (1617) and Deurigius (1665) (Willis, 1847). William Harvey (1651) believed that the male seed after entering the uterus become metamorphosed into an egg-like substance from which embryo developed (Moore et al., 2018)

Arnheim and Leeuwenhoek (1677) believed thought that the sperm contained the complete human in a diminutive form as a homunculus and when deposited in female it enlarges to develop into a complete human. Finally, Lazaro Spallanzani (1775) indicated the necessity of both sperm and oocyte in the development of human and the former concepts regarding the development and preformationism came to an end (Isfahani, 1970).

\section{J. The Quranic Description of The Matter of Creation of Man}

As we see, in several verses of the Holy Quran, it is described that Human being is created from a Nutfah ((نطف), The Quranic word Nutfah originally means 'a small part of a whole'. Contextually it means, 'the sperm, the ovum, the first stage of Human development.' (Ibn e Manzoor, 1882)

"O mankind, verily we gave you rise from a male and a female." (Hanbal, 2009)

It is described in a report by Abdullah Ibn e Masood:

The prophet SAW was questioned by a Jew regarding the matter of development of man to which he SAW replied that human develops from the NUTFAH of both male and female. The words Nutfah of male and Nutfah of female describe the sperm and the ovum, respectively. The word 'Nutfah' does not refer to the whole semen, rather it describes the small part of it i.e. sperm. This thing is further elaborated by Quranic verse:

"Then He made his posterity out of a quintessence (Sulalah) from a lowly fluid" (Quran 32:8)

One of the meanings of the word سشَكَكَّis 'sperm' (Steingass, 1884) The Arabic word 'sulalah' also means essence or the best part of a whole. As it is clear from the description of modern embryology that only a single sperm out of millions present in the semen is required for fertilizing the ovum and that the sperm that stands the best among millions wins this race of selection. The Quran aptly uses the term 'Sulalah' to describe this sperm. This verse states that out of the whole semen, only the little best part of it i.e. the best sperm is the cause of continuation of human race. In a narration from Prophet we see:

"The child does not come from all the semen" (Sahih Muslim Book 16, Hadith 157)

We conclude from here that out of the fluid of man a small part (sperm), and out of fluid female a small part (ovum) arerequired for fertilization. The Quran describes the union of these the gametes as Nutfatin Amshaj (mingled drop). As in a verse:

"Indeed, we created man from amerged drop so that we may test, and we made him listen and see.” (Quran 76:2) 
Important to note is that the word Nutfah is a singular and Amshaj is a plural. It points out that the two things i.e. the Nutfah of male and the Nutfah of female (sperm and ovum) unite two form a single Nutfah. This meaning can be further elaborated by the narration:

"And in a narration from Ibn e Abi Al Jaroud: Abu Jaffar (AS) regarding the verse 76:2, he (AS) said: "The mixing of water of man and water of woman." (Qummi, 2013). Same is described in various classical Muslim interpretations. (Razi: 1981; Tabri, 1994; Kashani, 1998; Tabarasi, 2005). We can infer that it is referring to the zygote which is a single cell produced by the union of male and female gametes, as the word means a small part of a whole and the zygote is also the smallest part of a developing human that contains the whole program for its development. Thus, the Nutfah (zygote) is also the first stage in the development of human being. It is referred to in other verses like Chapter 80 verse 19, Chapter 23 verse 13-14, Chapter 75 verse 37 etc.

Regarding the concept of preformationism or Epigenesis, the Quran clearly states that:

"He creates you in the wombs of the mothers, in stages one after another, in three darknesses." (Quran 39:6)

In the end of this description, we are encouraged to quote that some old Muslim scholars rejected the idea of creation of human from the menstrual blood. Allama Ibn e Hajar Asqalani says:

"Many anatomists falsely think that the male fluid has no part in the of the child except for the coagulation of blood, and that the embryo is formed from the menstrual blood. However, the prophet's hadith in this chapter confute this claim." (2009)

Throughout the course of history of embryological study until $20^{\text {th }}$ century it was believed that the embryo develops from menstrual blood, and it is fermented like the milk is fermented to make cheese. Furthermore, it was also a celebrated view that only the male has the part in the formation of child and the female is there just to provide the nourishment. However, the Islamic accounts state it like:

1. Embryo is formed from the gametes (Nutfah) of both the male and female

2. Both the gametes unite to form a single entity (Nutfatin Amshaj i.e. the gamete)

3. That single entity i.e. the gamete grows in stages creation after creation to form the whole human being.

Although the idea of creation from male and female seeds was described by Hippocrates and it was also there in Epicurean beliefs, but it was veiled compact by the magnificence of Aristotelian knowledge and Galenic descriptions. Furthermore, the concept was hazy and was those ideas could not point out the nature of female seed (many considered the female seed to be the menstrual blood). They focused mainly on the Physiology of development. However, the Quran and Sunnah are clear in the view that both male and female gametes unite to form a zygote which grows in stages to develop into a complete human.

\section{Conclusion}

The Islamic scripture, the Quran contains the exact and thorough account of the matter of human development, such an approach was non-existent in the time of its revelation. The revelation of such knowledge from an illiterate person in the era of least scientific technology is stunning and miraculous. Who could have divulged this information to him except by the Creator of this universe!

\section{References}

Aquinas, T. 1882. "Editio Leonina.” Rome: Ex Typographia Polyglotta SC. de propaganda Fide.

Asqalani, I. H. 2009. "Fath Ul Bari Sharah Sahih Bukhari." Pakistan: Maktabah Ashaab U1 Hadees.

Bailey, C. 1910. "Lucretius on The Nature of Things. London: Clarendon Press.

Bhishagratna KKL. 1907. “An English Translation of The Sushruta Samhita.” India: Bhishagratna KKL

Blackman, A. M. 1916. “The Pharaoh's Placenta and the Moon-God Khons.” The Journal of Egyptian Archaeology 3(1): 23549. doi: $10.2307 / 3853534$.

Book of Job 10:10.

Brock A. J. 1916. "Galen On the Natural Faculties.” London: G.P. Putnam's Sons.

Hanbal, A. 2009. "Musnad Imam Ahmad bin Hanbal.” Pakistan: Maktabah Rahmaniyya.

Harimoto, Kengo. 2011. "In Search of The Oldest Nepalese Manuscript.” Rivistadegli Studi Orientali 84: 85-88.

Hart, M. H. 2000. “The 100: A Ranking of the Most Influential Persons in History.” New York: Citadel. 
Heartland, E. S. 1909. "Primitive Paternity; The Myth of Supernatural Birth in Relation to the History of Family." London: London D Nutt.

https://www.poetryintranslation.com/PITBR/Greek/Eumenides.php

Ibn e Manzoor M. 1882. “Lisan Ul Arab.” Bairut: Dar e Sadir.

Isfahani, R. 1970. "Mufridat Ul Quran.” Pakistan: Sheikh Shams Ul Haq.

Kashani, F. 1998. "Kitab As Safi fi Tafseer Al Quran.” Iran: Dar Ul Kutub Al Islamia.

Kitchell, K. F., and Resenick I. M. 1999. “On Animals: A Medevial Summa Zoologica.” Baltimore: John Hopkins University Press.

Kleiss, E. 1964. "Historia de la Embriologia Y teratologia." Merida, Venezuela: Tallers Grafio Universitarios.

Maienschein, Jane. 2018. "Epigenesis and Preformationism," The Stanford Encyclopedia of Philosophy, Edward N. Zalta (ed.), USA: Stanford University.

Meyer, A. W. 1939. “The Rise of Embryology.” California: Stanford University Press.

Moore, KL., Persaud, TV., and Torchia MG. 2018. "The Developing Human-E-Book: Clinically Oriented Embryology". Netherland: Elsevier.

Needham J., and Hughes A. 2015. "A History of Embryology.” Cambridge: Cambridge University Press.

Oppenheimer, J. M., and Willier, B.H. 1964. "Foundations of Experimental Embryology." Prentice-Hall: Englewood, Cliffs, N.J.

Peck, AL. 1943. “Aristotle Generation of Animals.” London: Harvard University Press.

Potter, Paul. "Hippocrates, Vol X: Generation, Nature of the Child Diseases 4." Cambridge: Harvard University Press.

Qummi, Al. 2013. "Tafseer Al Qummi." Qum: Mossissa Imam Mehdi.

Razi, FD. 1981. "Tafseer Al Fakhr e Razi Al Mushtahir bi At- Tafseer Al Kabeer WaMafatih Ul Ghaib.” Bairut: Dar Ul Fikr.

Robert, Willis. 1847. “The Works of William Harvey.” London: C. and J. Adlard.

Sahih Muslim Book 16, Hadith 157.

Sherazi, N. M. 2005. “180 Questions: Enquiries about Islam.” United Kingdom: Islamic Education Board.

Steingass, F. 1884. "The students Arabic-English Dictionary." London: Crosby Lockwood and Son.

Stopes, Marie C. 1923. "Contraception (Birth Control) Its Theory, History, and Practice.” London: J. Bale, Sons \& Danielsson. Tabarasi, AFH. 2005. "Majma Ul Bayan fi Tafseer il Quran.” Lebonon:Dar Ul Uloom Li TehqeeqWa At TabaaWa An NasharWa At Tauzee

Tabri MIJ. 1994. “Tafseer Tabri Jami Ul Bayan An Taweel Il Quran.” Bairut:Mossasa tur risala.

Webb A. 1848. "Pathologic Indica: The Anatomy of Indian Diseases.” India: Messers. Thacker and Co.

Wisdom of Solomon vii:2 